薄肉構造物解析のための高次多項式内挿変位関数を用いた 完全適合型長方形平板有限要素

\title{
A COMPLETELY COMPATIBLE RECTANGULAR PLANER SHELL ELEMENT WITH HIGHER-ORDER POLYNOMIAL INTERPOLATION DISPLACEMENT FUNCTIONS FOR ANALYSIS OF THIN-WALLED STRUCTURES
}

上谷宏二*, 大神勝城**

Koji UETANI and Katsuki OHGAMI

\begin{abstract}
A new exactly compatible rectangular planer shell element on the basis of Von Karman's plate theory, whose displacement fields are approximated with higher-order polynomial interpolation functions, is proposed in this paper. The compatibility conditions at any type of interelement boundary can be exactly and easily expressed by means of the boundary tangential vectors. Very good results in FEM analyses can be obtained by using the proposed elements, with smaller number of degrees of freedom compared to some other efficient and reliable elements. The efficiency of the proposed element is demonstrated by some basic example analyses.
\end{abstract}

Keywords : FEM, rectangular planer shell element, Von Karman's plate theory, compatibility condition, element boundary tangential vector

有限要素法, 長方形平面シェル要素, フォン.カルマンの板理論, 適合条件, 要素境界接線ベクトル

\section{1. 緒言}

本論文の目的は，法線保持と平面応力の仮定に基づくKirchhoff平 板理論が適用できる十分薄い平板で構成された建築および土木構造 物を対象とし，高次多項式内挿変位関数を用いた収束性能のよい完 全適合型長方形平面シェル要素を提案することである。

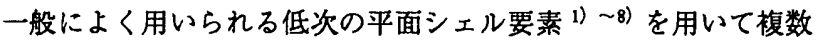
部材から成る構造物の全体挙動を精度良く解析するには，多数の要 素分割数と自由度数が必要となるため現在の計算機能力をもってし ても不十分な場合が多い。とりわけ，局部座屈が生じる場合は細か い要素分割と小刻みの増分載荷ステップが要求されるので計算負荷 は更に大きなものとなる。そのために、より少ない自由度数で精度 の高い解析が行える平面シェル要素の提案が求められている注1)。

長方形板曲げ要素に関しては、Bognerによって提案された双 3 次 完全多項式撓み関数を持つ適合高次要素が、低次要素に比べて良好 な収束性能を示すことが一般によく知られている 10)、11)。このこ とは，平面シェル要素に対しても完全適合型高次要素を構成できれ ば，同様の良好な取束性能が得られるであろうことを示唆してい ろ。平面シェル要素は、要素単体の初期形状が平面であり、折れ板 構造や多面体近似された曲面板などから構成される構造の解析にお いて、曲げ変形と面内変形の両方が生じる場合を扱う要素である。
平面シェル要素では、任意の角度で交わる要素間の境界線上で板の 面内および曲げ変位が相互に関連する適合条件を扱う必要がある。 しかし、このような適合条件を過不足なく完全に満足させることが 困難であることから、完全適合型高次要素が未だ提案されておらず 注2)、長方形要素が適用できる形状の構造物に対しても一般に非遮 合低次平面シェル要素が使用されている。適合条件を満足させるた めの一つの試みとして, Drilling Rotationと呼ばれる中央面の法湶

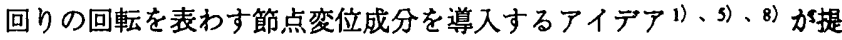
案されている。しかし、この方法では 1 節点に対して 1 個の回転成 分のみ定義されるので、節点を共有する複数の要素境界の各々の回 転角成分を一意に記述することができず、一般に適合条件を蕨密に 满足させることができない。

ここに新たに提案する要素は、Kirchhoff板理論に基づく長方形平 面シェル要素であり、完全適合を満たす 8 節点高次要素である。夜 位関数は、曲げ変位についてはBogner の要素と同じ 3 次の撓み関 数、面内变位についても暁み関数との対応において 3 次関数を探用 する。4 隅の節点变位成分は、節点の 3 方向の並進成分と、ここで 新たに定義する 2 本の要素境界接線べクトルの 4 個の独立な回転角 成分、および㨝れ率の計 8 個から成り立っている。中間節点の率位 成分は、要素境界に沿う要素座標系変位成分と要素境界の法線を基
* 京都大学工学部建築学教室 教授. 工博

** 日鐵プラント設計株式会社
Prof., Dept. of Architecture, Faculty of Engineering, Kyoto University, Dr. Eng. Nittetsu Plant Designing Corporation 
準にして回転する面内回転角成分からなる。哭琵境界接線べクトル とは、4 隅の節点において要素境界線に接して埋め込まれた単位へ クトルである。要素境界接線ベクトルという概念を新たに導入した ことにより、境界上の節点の变位成分を陊接要素間で一致させるだ けで全ての適合条件を過不足なく満足させることができる。従来の 要素では、要素境界の回転角成分を特に取り入れていなかったこと が、複数の要素が複雑に交差する境界での適合条件の記述を困難に し、完全適合型平面シェル要素の実現を阻んだ理由の 1 つであると 考えられる。

瞵接要素間で面内剪断剛性が不連続に変化する場合などは、その 要素間境界で面内剪断変形角に不連続が生じるため、これを表現で きる変位場を設定する必要がある。つまり、曲げ変位は䍡み角の連 続までを満たすC 1 連続であるのに対し、面内変位は本来 C 0 連続と すべきである。この要素では、過剩な連続性を課すことなく、要素 淁界線上に抢ける变位場の適合条件が過不足なく満足される。その 結果として、面内変位および曲げ変位の再方について良好な精度の 解が得られると期待される。

また、ここで提䓩する幾何学的非線形効果は、搐み勾配の 2 次項 だけを取り入れたVon Karmanの大撓み板理論の非線形昰と、増分 ステップの途中でも常に要素に付随して移動する要素移動座標系の 組み合わせよって簡便かつ精度良く考留できる。この方法の有効性 は、梁要素を用いた骨組解析 12)，13)について㬰証されている。これ に对して、增分ステップ中は移動しない座標系を用いるTotal Lagrange流やUpdated Lagrange流の定式化では、全体座屈まで含 めた挙動の追跡を行うために面内変位に関する非線形項まで全て含 んだ非線形歪を採用する必要があり, 高次要素では皘分計算負荷が 一般に多大となる難点がある。一方、Von Karman理論に基づく要 秦ではこの負荷が大幅に軽減される。ただし，要素移動座標系の定 式化については報を改めて紹介し，本報で示す解析例では要素移動 座標系を考慮しない。

ここで提案する要素の有効性は、既往の論文の中で提示されてい る高性能な要素と精度を比較することによって検証する。

\section{2. 板要秦の定式化}

2-1。座標系の設定

図 1 に示す要素座標系 $\left(O^{E}-\xi \eta \zeta\right)$ と、系座標系（o- $\mathrm{x} y$ z）を用いる。本論文では、これらを固定座標系として扱う。 $2-2$ 。変位関数

板要素の要素座標系は、4 隅の節点のうち 1 点を原点にして、2 辺の要素境界に $\xi$ 軸扔よび $\zeta$ 軸を設置する。板中央面上の $\xi 、 \eta 、$ $\zeta$ 方向変位をそれぞれ $u^{\mathrm{E}}(\xi, \zeta), v^{\mathrm{E}}(\xi, \zeta), w^{\mathrm{E}}(\xi, \zeta)$ と表示し、係

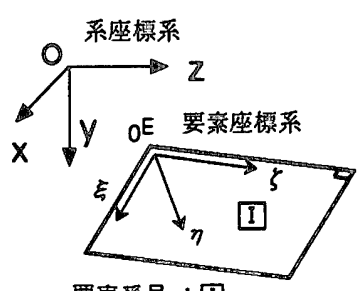

要妻番号. : 团

図 1：座樌系

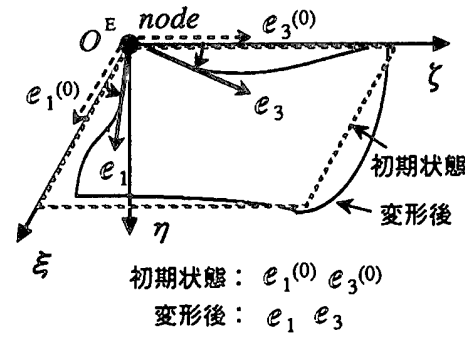

图 2：要素境界接線ペクトル
数の数を 40 個にして 位関数は、面内の勭断裂形を精度よく表現することができる。

$$
\begin{aligned}
& u^{\mathrm{E}}(\xi, \zeta)=\sum_{\mathrm{i}=1,12} \alpha_{\mathrm{i}} \Phi_{\mathrm{i}}(\xi, \zeta) \\
& =\left[\begin{array}{llllllllllll}
1 & \zeta & \zeta^{2} & \zeta^{3} & \xi & \xi \zeta & \xi \zeta^{2} & \xi \zeta^{3} & \xi^{2} & \xi^{2} \zeta & \xi^{2} \zeta^{2} & \xi^{2} \xi^{3}
\end{array}\right] \\
& \text { - }\left[\begin{array}{lll}
\alpha_{1} & \alpha_{2} \ldots \alpha_{12}
\end{array}\right]^{t}
\end{aligned}
$$

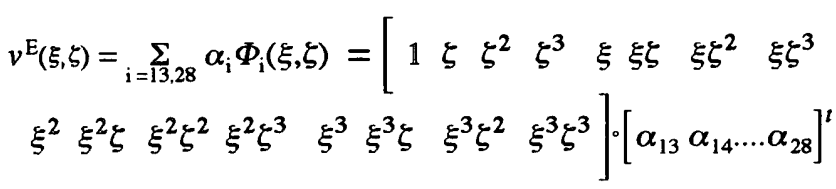$$
w^{\mathrm{E}}(\xi, \zeta)=\sum_{\mathrm{i}=29,40} \alpha_{\mathrm{i}} \Phi_{\mathrm{i}}(\xi, \zeta)
$$

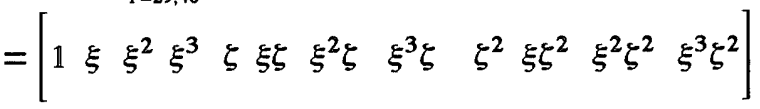$$
\cdot\left[\begin{array}{lll}
\alpha_{29} & \alpha_{30} \ldots \alpha_{40}
\end{array}\right]^{t}
$$

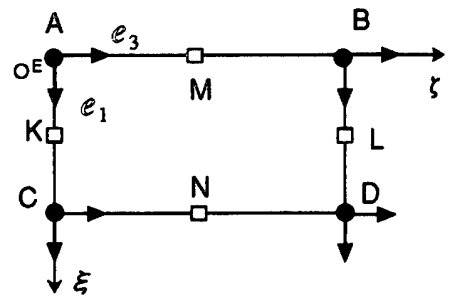

図 3：節点の配置

\section{2-3. 要秦境界接線ベクトルの定㼁}

要素境界接線ベクトルとは、図 2 に示すように 4 隅の節点におい て要素境界の 2 辺の接線方向に埋め込まれた単位べクトル $\mathbb{C}_{1}, \mathbb{C}_{3}$ である。要素境界辺の変形に追従して互いに独立に回転移動する。 $2-4$. 板要㓗の変位成分

要素の变位成分は図 3 に示す節点A-D抢よび中間節点K-Nに属す る計 40 個の成分で構成される。

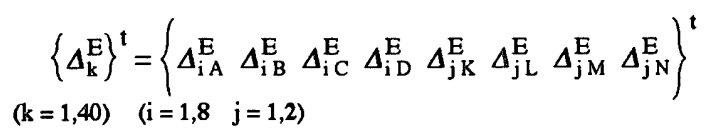

ここで、例えば 節点 $\mathrm{A}$ の変位成分：

$$
\left.\underset{(\mathrm{i}=1,8)}{\left\{\Delta_{\mathrm{iA}}^{\mathrm{E}}\right.}\right\}^{\mathrm{t}}=\left[\begin{array}{llllll}
u_{\mathrm{A}}^{\mathrm{E}} & v_{\mathrm{A}}^{\mathrm{E}} & w_{\mathrm{A}}^{\mathrm{E}} & v, \underset{\xi \zeta \mathrm{A}}{\mathrm{E}} u, \zeta_{\zeta \mathrm{A}}^{\mathrm{E}} v, \underset{\zeta \mathrm{A}}{\mathrm{E}} v, \underset{\xi \mathrm{A}}{\mathrm{E}} w, \xi_{\xi \mathrm{A}}^{\mathrm{E}}
\end{array}\right]
$$

中間節点Mの変位成分:

$$
\begin{aligned}
& \left\{\Delta_{\mathrm{jM}}^{\mathrm{E}}\right\}^{\mathrm{t}}=\left\lfloor u_{\mathrm{M}}^{\mathrm{E}} u_{\zeta \mathrm{M}}^{\mathrm{E}}\right\rfloor \text { or }\left\lfloor w_{\mathrm{M}}^{\mathrm{E}} w_{\zeta \mathrm{M}}^{\mathrm{E}}\right\rfloor \\
& (\mathrm{j}=1,2) \quad \xi \text { 軸上 } \quad \zeta \text { 軸上 } \\
& \text { ただし、( ) }, \xi \boxminus \frac{\partial()}{\partial \xi} \text { であり他も倣う。 }
\end{aligned}
$$

また、節点Aにおける要素境界接線ベクトルは、要素座標系の基底

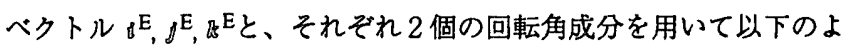
うに表わせる。

$$
\left\{\begin{array}{l}
e_{1 \mathrm{~A}} \\
e_{3 \mathrm{~A}}
\end{array}\right\}=\left[\begin{array}{ccc}
1 & v,{ }_{\xi \mathrm{A}}^{\mathrm{E}} & w, \xi \overline{\mathrm{A}} \\
u, \mathrm{\zeta}_{\mathrm{A}}^{\mathrm{E}} & v, \underset{\zeta \mathrm{A}}{\mathrm{E}} & 1
\end{array}\right]\left\{\begin{array}{l}
f^{\mathrm{E}} \\
j^{\mathrm{E}} \\
b^{\mathrm{E}}
\end{array}\right\}
$$

したがって、（3）式中の計 4 個の回転角は 2 辺の要素境界接線べク トルに属する変位成分であると捉え、（4）式のように区分けでき 
る。そこで、（2）式の節点の 8 個の変位成分を節点および接線ベク トルに属する成分にわけると（5）式のように表せる。ただし、式中 の右端の小添字 $1 、 3$ は接線ベクトル番号に対応する。

$$
\begin{aligned}
& \mathscr{C}_{1 \mathrm{~A}} \text { に対して }\left\{\Lambda_{\mathrm{qA} 1}^{\mathrm{E}}\right\}^{\prime}=|v, \underset{\xi \mathrm{A}}{\mathrm{E}} w, \underset{\xi \mathrm{A}}{\mathrm{E}}|,(\mathrm{q}=1,2) \\
& e_{3 \mathrm{~A}} \text { k対して }\left\{\Lambda_{\mathrm{qA} 3}^{\mathrm{E}}\right\}^{\mathrm{t}}=\left|u, u_{\zeta \mathrm{A}}^{\mathrm{E}} v,{ }_{\zeta \mathrm{A}}^{\mathrm{E}}\right| \\
& \left\{\Delta_{\mathrm{k}}^{\mathrm{E}}\right\}^{\mathrm{t}}=\left\{\Lambda_{\mathrm{pA}}^{\mathrm{E}} \Lambda_{\mathrm{qA} 1}^{\mathrm{E}} \Lambda_{\mathrm{qA} 3}^{\mathrm{E}} \cdots \Lambda_{\mathrm{pD}}^{\mathrm{E}} \Lambda_{\mathrm{q} D 1}^{\mathrm{E}} \Lambda_{\mathrm{q} D 3}^{\mathrm{E}} \Delta_{\mathrm{j} \mathrm{K}}^{\mathrm{E}} \cdots \Delta_{\mathrm{jN}}^{\mathrm{E}}\right\}^{\mathrm{t}} \\
& \text { ただし、 }\left\{\Lambda_{\mathrm{pA}}^{\mathrm{E}}\right\}^{\mathrm{t}}=\left\lfloor\begin{array}{llll}
u_{\mathrm{A}}^{\mathrm{E}} & v_{\mathrm{A}}^{\mathrm{E}} & w_{\mathrm{A}}^{\mathrm{E}} & v_{\xi 5 \mathrm{~A}}^{\mathrm{E}}
\end{array}\right\rfloor,(\mathrm{p}=1,4)
\end{aligned}
$$

\section{2ー5. 要素間境界における適合条件}

ここでは撓みのC 1 連続と面内変位のC 0 連続を 2 要素間境界を 例に説明する。初期状態の要素境界接線ベクトルの配固を四 4 に示 す。なお、2 個以上の要素から成る境界については、それぞれ 2 要 素の組合わせに対して同じ取り扱いができる。

\section{[1] 変位の連続条件}

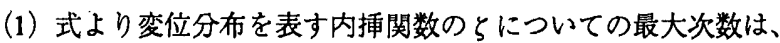

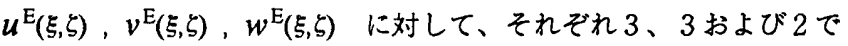
ある。したがって、ら方向の撓み曲線を決定するには、それぞれ $4 、 4$ および 3 の合計 11 個の条件が必要である。この要求に対し て、II側の要素境界では節点 $\mathrm{A}, \mathrm{B}$ において次の変位成分を用いれ ば、要素境界の撓み曲線が記述される。図中の右添字の最後の 2 文 字は要素番号と節点記号を示す。

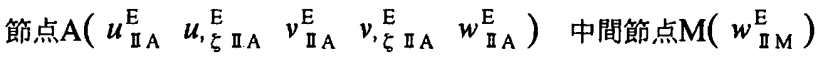

$$
\begin{aligned}
& \text { 節点 } \mathrm{B}\left(\begin{array}{lllll}
u_{\mathbb{I B}}^{\mathrm{E}} & u_{\zeta_{\zeta \mathbb{B}}}^{\mathrm{E}} & v_{\mathbb{I B}}^{\mathrm{E}} & v,{ }_{\zeta \mathbb{B}}^{\mathrm{E}} & w_{\mathbb{I B}}^{\mathrm{E}}
\end{array}\right)
\end{aligned}
$$

同様にして、I側の A B 間境界の変形を記述するために 11 個の変位 成分を用いる。要素間境界の適合条件は、これらの 2 つの要素の系 座標系節点変位成分を互いに一致させることによって満足させられ る。このことは、図 5 に示す系座標系原点から節点への位置ベクト $ル \mathbb{P}_{\mathrm{A}}, \mathbb{P}_{\mathrm{B}}$ と接線べクトルを用いて表した以下の条件式が成り立つ ことと等価である。

$\mathbb{P}_{\mathrm{A}}^{\mathrm{I}}=\mathbb{T}_{\mathrm{A}}^{\mathrm{I}} \quad \mathbb{P}_{\mathrm{B}}^{\mathrm{I}}=\mathbb{P}_{\mathrm{B}}^{\mathrm{II}} \quad e_{3 \mathrm{~A}}^{\mathrm{I}}=e_{3 \mathrm{~A}}^{\mathrm{I}} \quad e_{3 \mathrm{~B}}^{\mathrm{I}}=e_{3 \mathrm{~B}}^{\mathrm{I}} \quad w_{\mathrm{IM}}^{\mathrm{E}}=w_{I \mathrm{M}}^{\mathrm{E}}$

\section{［2］要秦境界楾の法線方向の撓み勾配の連続条件}

撓み勾配は、変位関数 $v^{\mathrm{E}}(\xi, \zeta) を \xi て ゙ 1$ 回微分して得られ、らに関 して 3 次関数である。そこで節点 $\mathrm{A}, \mathrm{B}$ の以下の撓み角と摸れ率の 計 4 個の変位成分を用いて、II側の撓み勾配が一意に決定される。

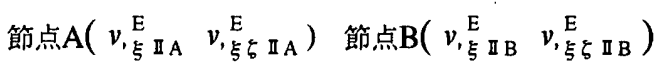

同様にしてI側でも撓み勾配が得られる。撓み勾配の連続条件は、こ れらの 4 個の系座標系節点変位成分を互いに一致させれば、常に満 足される。この条件は次のようにも書くことができる。

$$
\begin{aligned}
& \frac{\left(e_{1 \mathrm{~A}}^{\mathrm{I}} \times \Theta_{3 \mathrm{~A}}^{\mathrm{I}}\right)}{\left|\Theta_{1 \mathrm{~A}}^{\mathrm{I}} \times \Theta_{3 \mathrm{~A}}^{\mathrm{I}}\right|} \cdot \frac{\left(\Theta_{1 \mathrm{~A}}^{\mathrm{II}} \times \Theta_{3 \mathrm{~A}}^{\mathrm{II}}\right)}{\left|\mathbb{E}_{1 \mathrm{~A}}^{\mathrm{I}} \times \Theta_{3 \mathrm{~A}}^{\mathrm{II}}\right|}=\text { const } \text {. }
\end{aligned}
$$

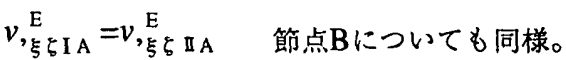

第 1 式は図 6 に示すように2 面のなす角度が不変で、撓み角が点 $\mathrm{A}$ ，Bで連続であること、また第 2 式は据れ率の連続条件を表す。 [3] 面内回転角の不連続条件

面内回転角は、变位関数 $w^{\mathrm{E}}(\xi, \zeta)$ を $\xi て ゙ 1$ 回微分して得られ、ら に関して 2 次関数である。この面内回転角は境界上で不連続にすべ きであり、節点 $A, M, B て ゙$ 互いに独立な変位成分として扱う。

$2-6$. 板要秦の基礎方程式

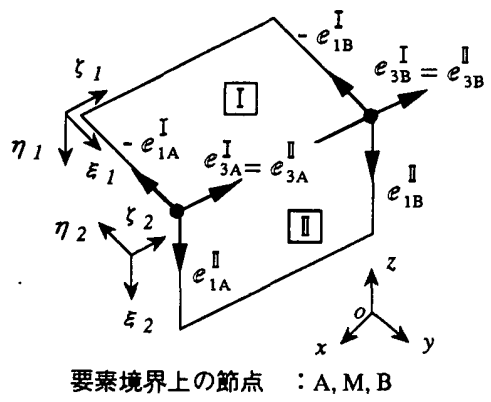

図 4：2 要素間境界の接線ベクトルの配贯

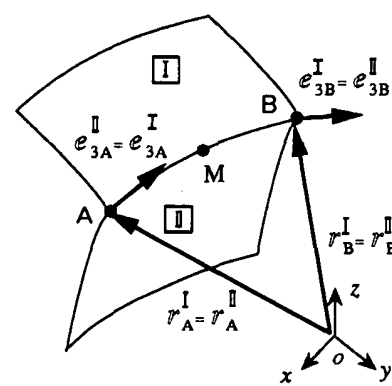

図 5：撓みの連続条件 に関する図

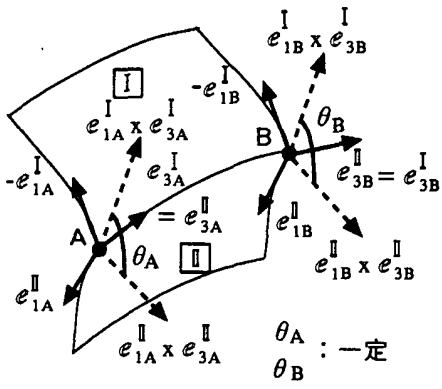

図 6: 撓み勾配の連続 に関する图
この板要素は、Von Karmanの板の大撓み理論の基本仮定に従っ ており、次の歪〜変位関係を満足している。

$$
\begin{aligned}
& \varepsilon_{1}=\varepsilon_{\xi}(\xi, \eta, \zeta)=u,{ }_{\xi}^{\mathrm{E}}+1 / 2\left(v,{ }_{\xi}^{\mathrm{E}}\right)^{2}-\eta \cdot v,{ }_{\xi \xi}^{\mathrm{E}} \\
& \varepsilon_{2}=\varepsilon_{\eta}(\xi, \eta, \zeta)=w,{ }_{\zeta}^{\mathrm{E}}+1 / 2\left(v, \frac{\mathrm{E}}{\mathrm{E}}\right)^{2}-\eta \cdot v,{ }_{\zeta \zeta}^{\mathrm{E}} \\
& \varepsilon_{3}=\varepsilon_{\xi \zeta}(\xi, \eta, \zeta)=u,{ }_{\zeta}^{\mathrm{E}}+w, \frac{\mathrm{E}}{\mathrm{E}}+\left(v, \frac{\mathrm{E}}{\mathrm{E}}\right) \cdot\left(v, \frac{\mathrm{E}}{\mathrm{E}}\right)-2 \eta \cdot v,{ }_{\xi \zeta}^{\mathrm{E}}
\end{aligned}
$$

（10）式に（1）式を代入し、これを時間で微分して速度式を導く と、次の歪速度と一般化変位速度の関係式が得られる。ただし、以 下の数式において、特に指摘しない限り同じ添字に関して総和則を 適用する。

$$
\dot{\varepsilon}_{\mathrm{k}}=B_{\mathrm{ki}} \cdot \dot{\alpha}_{\mathrm{i}} \quad(\mathrm{k}=1,3 \quad \mathrm{i}=1,40)
$$

応力速度と歪速度関係は、応力〜歪マトリックス $D_{\mathrm{k} l}$ を用いて以下 のように表せる。さらに、（11）式を代入すると、㐫力速度と一般 化変位速度関保式が得られる。

$$
\dot{\sigma}_{\mathrm{k}}=D_{\mathrm{k} l} \cdot \dot{\varepsilon}_{l}=D_{\mathrm{k} l} \cdot B_{l \mathrm{j}} \cdot \dot{\alpha}_{\mathrm{j}} \quad(\mathrm{j}=1,40 \quad l=1,3)
$$

\section{2-7. 座標変換則}

要素に関する一般化変位速度一要素座標系变位速度成分関係を定 数の保数マトリックスを用いて次式で表わせる。

$$
\dot{\alpha}_{\mathrm{i}}=H_{\mathrm{i} \mathrm{j}} \cdot \dot{\Delta}_{\mathrm{j}}^{\mathrm{E}}
$$

要素座標系と系座標系の節点变位速度成分の関係は、以下の 2 項 
目で定敄できる。

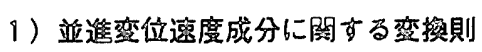

要素座標系と系座標系の基底ベクトルの関係は、次式で表わせ る。

$$
{ }_{b} \mathrm{E}=C_{\mathrm{i}} \cdot \dot{b}_{\mathrm{j}} \quad(\mathrm{i}=1,3 \mathrm{j}=1,3)
$$

このとき、2つの座標系の並進変位速度成分の関係式が、次式で得 られる。

$$
\begin{gathered}
\dot{\Delta}_{\mathrm{iA}}=C_{\mathrm{ji}} \cdot \dot{\Delta}_{\mathrm{jA}}^{\mathrm{E}} \\
\text { ただし、 }\left\{\dot{\bar{\Delta}}_{\mathrm{iA}}\right\}^{\prime}=\left[\begin{array}{lll}
\dot{u}_{\mathrm{A}} & \dot{v}_{\mathrm{A}} & \dot{w}_{\mathrm{A}}
\end{array}\right],\left\{\dot{\Delta}_{\mathrm{iA}}^{\mathrm{E}}\right\}^{\prime}=\left[\begin{array}{lll}
\dot{u}_{\mathrm{A}}^{\mathrm{E}} & \dot{v}_{\mathrm{A}}^{\mathrm{E}} & \dot{w}_{\mathrm{A}}^{\mathrm{E}}
\end{array}\right]
\end{gathered}
$$

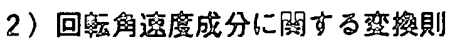

図7に示すように、ベクトル 成分は、 $\mathrm{z}$ 軸回りの回転角 $\theta$ と、 $\mathrm{x} y$ 平面からの回転角 $\varphi$ である。 ベクトルヒと系座標系基底ベクトルの関係は次式で表せる。

$$
\begin{gathered}
\mathscr{B}_{\mathrm{i}}=R_{\mathrm{ij}} \text { b }_{\mathrm{j}} \\
\text { ただし、 } \\
\left\{\begin{array}{l}
R_{1 \mathrm{j}} \\
R_{3 \mathrm{j}}
\end{array}\right\}=\left[\begin{array}{lll}
\cos \theta_{1} \cos \varphi_{1} & \sin \theta_{1} \cos \varphi_{1} & \sin \varphi_{1} \\
\cos \theta_{3} \cos \varphi_{3} & \sin \theta_{3} \cos \varphi_{3} & \sin \varphi_{3}
\end{array}\right]
\end{gathered}
$$

要素座嫖系の基底ベクトルとの関係は、（16）式に（14）式を代入 して次のように導かれる。

$$
\mathfrak{G}_{\mathrm{i}}=R_{\mathrm{i}} C_{\mathrm{kj}} \stackrel{B}{\mathrm{~B}}_{\mathrm{k}}^{\mathrm{E}} \quad(\mathrm{i}=1 \text { or } 3, \mathrm{j}=1,3 \mathrm{k}=1,3)
$$

ここで、節点 $\mathrm{A} に$ に関して（3）式と（17）式を等置して、回転角成 分の関係を導くと次式が得られる。

$$
\begin{array}{ll}
u_{\zeta \mathrm{A}}^{\mathrm{E}}=R_{3 \mathrm{j}} \cdot C_{1 . \mathrm{j}} & , \quad v_{\zeta \mathrm{A}}^{\mathrm{E}}=R_{3 \mathrm{j}} \cdot C_{2 . \mathrm{j}} \\
v, \underset{\xi \mathrm{A}}{\mathrm{E}}=R_{1 \mathrm{j}} \cdot C_{2 . \mathrm{j}} & , \quad w_{\xi \mathrm{A}}^{\mathrm{E}}=R_{1 \mathrm{j}} \cdot C_{3 . \mathrm{j}}
\end{array}
$$

（18）式を速度表示することにより、系座標系と要素座標系の回転 角速度成分の間の 4 つの関係式が䢘かれる。

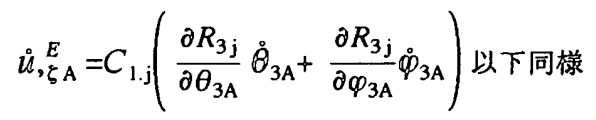

ここでは、節点Aにおける回転角の变化は微小であると仮定して、

（19）式の右辺の境界接線ベクトルの回転角速度成分の係数は,初期 状態の 2 つの座標系の位直関係から得られる定数として扱う注3)。 きた、层れ率速度は座標系に依存しない变数であり、（15）式と

(19）式に据れ率速度の項を加えれば、系座標系と要素座標系節点 索位速度成分の間の変換則が $(20)$ 式で表せる。なお、右辺の $E_{\mathrm{jkA}}$ は、定数マトリックスである。

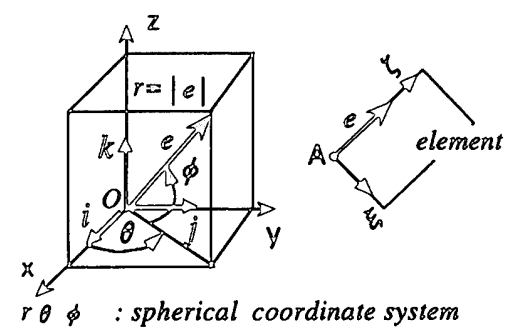

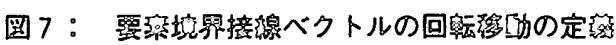

$$
\begin{aligned}
& \text { ここで } \quad \dot{\Delta}_{\mathrm{jA}}^{\mathrm{E}}=E_{\mathrm{jkA}} \dot{\Delta}_{\mathrm{kA}} \quad(\mathrm{j}=1,8 \mathrm{k}=1,8)
\end{aligned}
$$

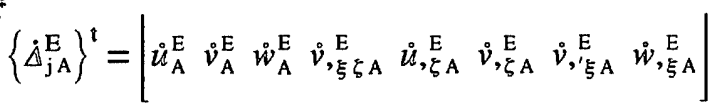

$$
\begin{aligned}
& \left\{\dot{\Delta}_{\mathrm{jA}}\right\}^{\prime}=\left[\begin{array}{llllllll}
\dot{u}_{\mathrm{A}} & \dot{v}_{\mathrm{A}} & \dot{w}_{\mathrm{A}} & \dot{v}_{, \xi \zeta \mathrm{A}}^{\mathrm{E}} & \dot{\theta}_{1 \mathrm{~A}} & \dot{\varphi}_{1 \mathrm{~A}} & \dot{\theta}_{3 \mathrm{~A}} & \dot{\varphi}_{3 \mathrm{~A}}
\end{array}\right]
\end{aligned}
$$

要素の全節点変位成分の速度是に対する変換則は、要素を構成する 他の隅節点に対して（20）式と同じ変換式を導き、さらに中間節点 に属する変位速度成分には座標变換を施さずに、それらの関係式を まとめれば（21）式で表される。

$$
\dot{\Delta}_{\mathrm{j}}^{\mathrm{E}}=E_{\mathrm{jk}} \dot{\Delta}_{\mathrm{k}} \quad(\mathrm{j}=1,40 \mathrm{k}=1,40)
$$

（13）式と（21）式から、一般化変位速度成分と系座標系節点変位 速度成分の関保式は、以下のように求められる。

$\dot{\alpha}_{\mathrm{i}}=H_{\mathrm{ij}} \dot{\Delta}_{\mathrm{j}}^{\mathrm{E}}=H_{\mathrm{ij}} E_{\mathrm{jk}} \dot{\Delta}_{\mathrm{k}}=L_{\mathrm{ik}} \dot{\Delta}_{\mathrm{k}} \quad(\mathrm{i}=1,40 \mathrm{j}=1,40 \mathrm{k}=1,40)$

\section{3. 忞線㓮性方程式}

系座標系に関する要素の接線剖性方程式は、仮想仕事式に基づく 通常の方法により以下のように導びける。

$$
\begin{gathered}
K_{\mathrm{mn}} \AA_{\mathrm{n}}=\dot{f}_{\mathrm{m}}(\mathrm{m}=1,40 \mathrm{n}=1,40) \\
\text { ここで、 } K_{\mathrm{m} \mathrm{n}}=L_{\mathrm{im}}\left[\int\left(\frac{\partial B_{\mathrm{ki}}}{\partial \alpha_{\mathrm{j}}} \sigma_{\mathrm{k}}+B_{\mathrm{ki}} D_{\mathrm{k} l} B_{l \mathrm{j}}\right) \mathrm{dv}\right] L_{\mathrm{j} \mathrm{n}} \\
\quad(\mathrm{i}=1,40 \quad \mathrm{j}=1,40 \quad \mathrm{k}=1,3 \quad l=1,3)
\end{gathered}
$$

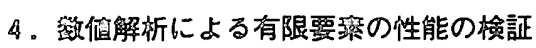

4ー1，经の曲げ性能（既往の諭文の計算熘との比較）

既往の論文として比較に用いるのは、3 件の論文であり要素の特 徴は以下の通りである。

(Shmuel L.Weissman and Roberi L.Taylorの要嚓14)、および

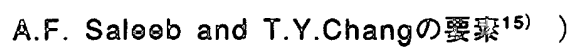

- Mindlin-Reissner板理論による定式化 ・Hellinger-Reissner 変分原理の適用 $\cdot \mathrm{C} 0$ 連続の 4 節点 4 辺形要素 · 内挿関数は双 1 次(billinear interpolation)

\section{(M.Oriz and G.R.Morrisの垔骤16) )}

Kirchhoff板理論による定式化 ・C0連続の高次Kirchhoff板要 素 . 9 節点および 16 節点 4 辺形要素（内挿関数の最大次数 は、それぞれ 2 および 3 ） ・節点に属する末知数の数は 4 個 （变位成分 3 個の他に 1 個の荷重ポテンシャル）

これらの論文で、提案された有限要素の基本性能を示す図表の中 に、今回提筑する有限要素（NASP）による結果を示している。 図 8,9 は、自由度総数（DOF）と計算精度の関係を表わしている。 提管する要素は、L.Taylorや T.Y.Changの要素に比ベて十分高い榷 度を有している。なお、論文から引用したグラフのDOFの中には、 要素内の仮想内力の自由度数（12 個 ${ }^{14)}$ および15個 $\left.{ }^{15)}\right)$ を算入 している。また、図10のM.Ortizの要素との比較でも同等もしくは それ以上の崝度がある。一方、图 11 の搌れ ${ }^{15)}$ に関しては収束ライ ンから若干ずれがあるが、4要素モデルであればほとんど一致して 
おり実用上は特に問題ない。

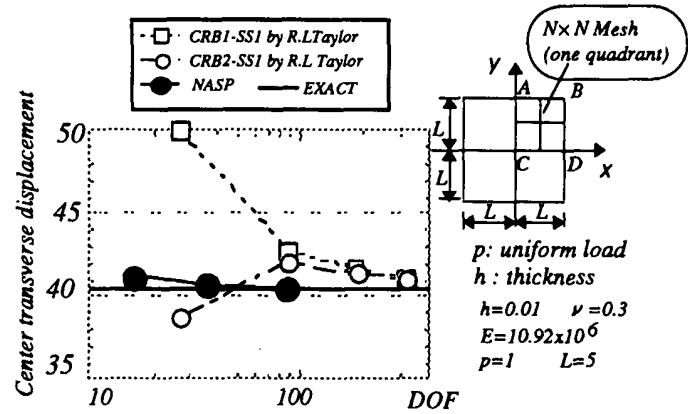

S.L. Weisman,R.L. Talor の要栔との精度比較

\section{図 8： 等分布荷重下の周辺支持板の板曲げ}

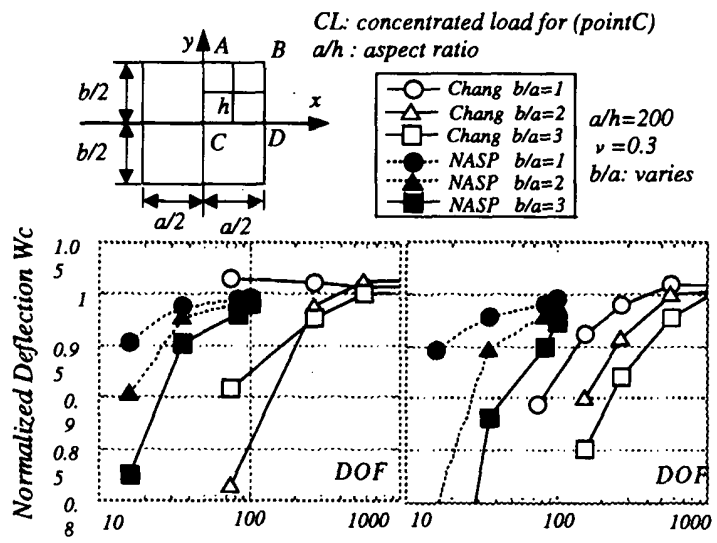

(a) $S S$ - $C L$

(b) $C-C L$

A.F. Saleeb and T.Y.Changの要軎との性能比較

図 9：集中荷重下の周辺支持および固定板の板曲げ

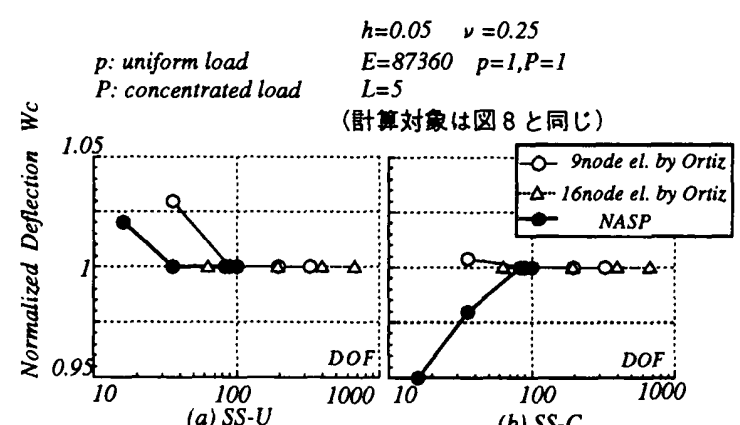

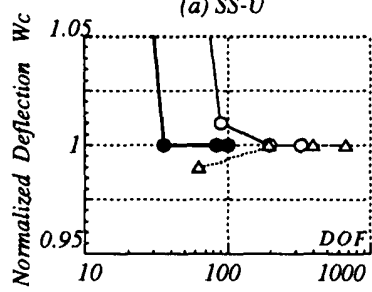

(c) $\mathrm{CL}-\mathrm{U}$ (b) $S S$ - $C$

(d) CL-C

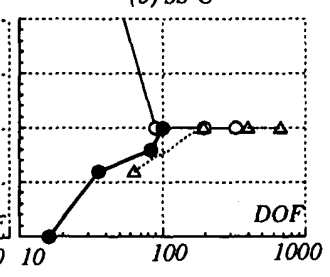

M.Ortiz and G.R.Morrisの要素との性能比㜞

図10：等分布荷重 $(U) 、$ 乘中荷重 $(C)$ 下の 周辺支持 (S S ) や周辺固定 $(C L)$ された板 の板曲けf

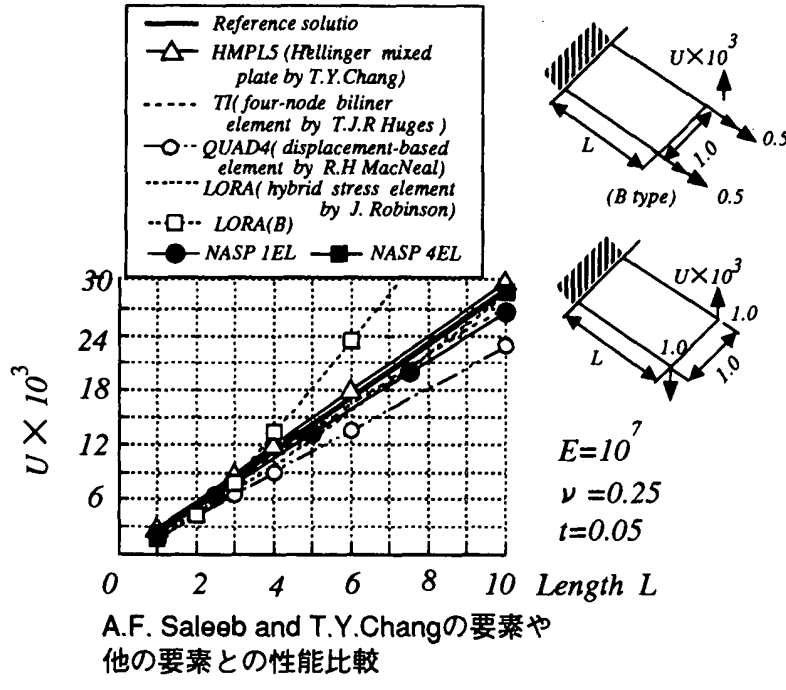

図 11 : 単一要秦の据れ

\section{$4-2$ ． 板の面内曲げ性能}

(1) 片持ち短梁に関する既往の論文の計算值との比較

Adnan Ibraimbegovic and Edward L.Wilsonの要素 ${ }^{8)}$ の特徽は以 下の通りである。

・板曲げ剛性は 4 節点離散化Kirchhoff板要素、面内剛性は

Drilling rotation 考慮した平面シェル要素

・節点の変位成分の数は 6 個で 1 要素の自由度総数は 24 。

図12の縦軸は、Timoshenkoの弾性論 17) の中の理論式による值を 用いて自由端の中央の变位を正規化し、横軸は曲げに関する自由度 数を除いて 2 次元面内問題における自由度数のみを示す。また解析 では端部の剪断荷重は要素辺に沿って等しく分布させ、 $\mathrm{y}=0$ の固定 端では、 $\mathrm{z}$ 方向変位を拘束している。計算精度は分割が粗くても良 好であり収束性も良い。
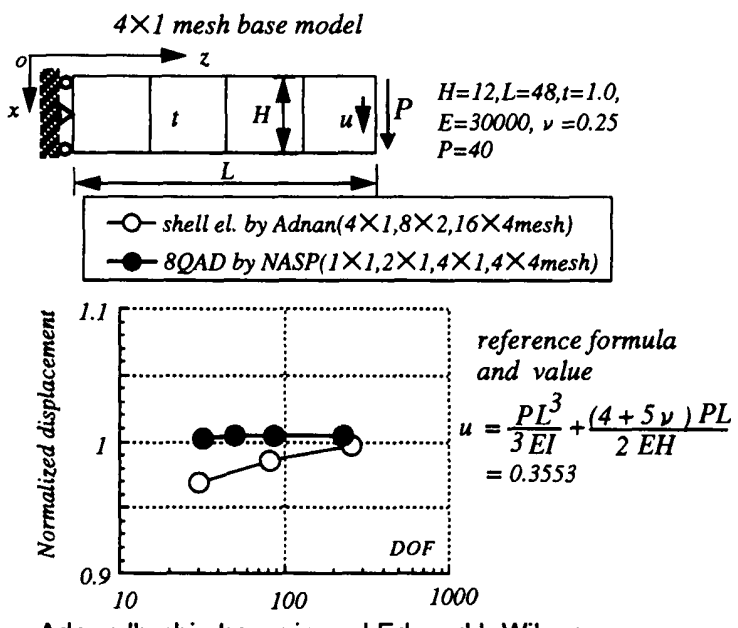

Adnan Ibrahimbegovic and Edward L. Wilson の要蛪との性能比較

\section{図12：板の面内曲けf}

\section{（2）面内回転を伴う变形性能の検証}

要素境界上で節点の面内回転角が不連続（C０連続）であるタイ プ1と、C 1 連続を仮定したタイプ 2 のモデルを設定して面内変位

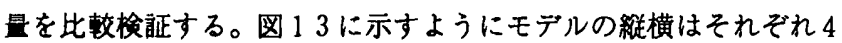


分割され、長さと柧厚をパラター夕に設定する。解析結果は表」に 示されている。西者の変形旦は板厚がすべて同じであれば、ほとん どー致している。一方、板厚に段差があれば傾向的にタイプ1の方 が变形が大きく、要素間の板厚差が大きいほど耐者に無視でさない 差異が見受けられる。したがって、面内剛性が不連続である場合 に、C 0 連続を忠実に設定できる今回の要素は、計算精度をより向 上させるうえで有効である。

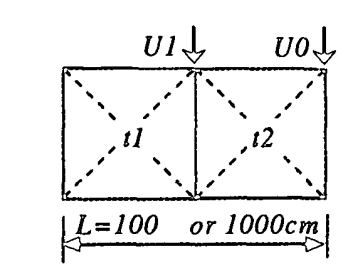

$t 1=1.0 \mathrm{~cm} \times n \quad t 2=1.0 \mathrm{~cm}$ $d=50 \mathrm{~cm} \quad \nu=0.3 \quad E=2100 \mathrm{t} / \mathrm{cm} 2$

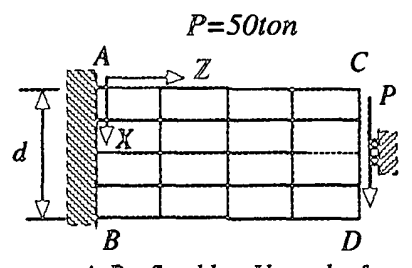

$A-B$ : fixed but $U, z$ to be free $C \cdot D: W=W, x=0$

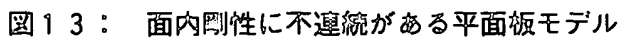

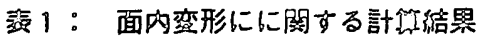

1. パラタータ L/D（族可一定）の奶合

\begin{tabular}{|c|c|c|c|}
\hline \multirow{2}{*}{$L D$} & \multicolumn{3}{|c|}{$V=0.0$} \\
\cline { 2 - 4 } & $C B$ & $D C B$ & $D C B / C B$ \\
\hline 2 & 0.302746 & 0.302747 & 1.00 \\
\hline 20 & 191.6077 & 191.6077 & 1.00 \\
\hline
\end{tabular}

\begin{tabular}{|c|c|c|c|}
\hline \multirow{2}{*}{$L / D$} & \multicolumn{3}{|c|}{$y=0.3$} \\
\cline { 2 - 4 } & $C B$ & $D C B$ & $D C B / C B$ \\
\hline 2 & 0.328353 & 0.328356 & 1.000009 \\
\hline 20 & 188.8726 & 189.049 & 1.000933 \\
\hline
\end{tabular}

note) type $1(D C B$ : disncontinuous boundary rotation)

type 2 ( $C B$ : continuous boundary rotation)

$D=50 \mathrm{~cm}, t=1.0 \mathrm{~cm}, E=2100 \mathrm{t} / \mathrm{cm} 2$

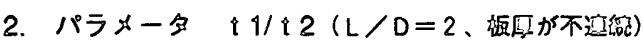
Maximum displacement at loadind point

\begin{tabular}{|c|c|c|c|c|c|}
\hline & $t 1 / s 2$ & 1 & 2.5 & 5 & 10 \\
\hline \multirow{2}{*}{$D C B$} & $U 0 d$ & 0.328356 & 0.211892 & 0.159563 & 0.128629 \\
\cline { 2 - 6 } & $U 1 d$ & 0.164193 & 0.079472 & 0.043986 & 0.02348 \\
\hline \multirow{2}{*}{$C B$} & $U O C$ & 0.328353 & 0.210835 & 0.157496 & 0.125883 \\
\cline { 2 - 6 } & $U 1 c$ & 0.164176 & 0.079504 & 0.044011 & 0.023586 \\
\hline ratio & UOd/UOd & 1.00001 & 1.00501 & 1.01312 & 1.02181 \\
\hline
\end{tabular}

note) $L D=2, E=2100 \mathrm{t} / \mathrm{cm} 2, D=50 \mathrm{~cm}, t 2=1.0 \mathrm{~cm}, \nu=0.3$

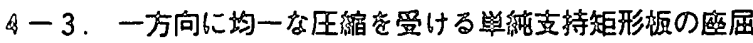

座屈固有值解析によって、要素の幾何学的非線形効果の検証を行 なう。計算モデルは、1／4対称モデルである。計算結果はメッ シュ效をパラメータとして表 2 に整理されている。検討の結果、提 瑟する要素は粗い要素分割であっても、座屈荷重を比較すると良好 な精度を有していることがわかる。

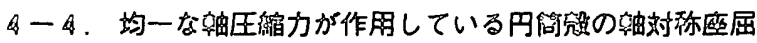

円筒凯の形状は、節点に初期変位を与えて近似的に表現する。要 琭分割数は 6 個である。計算は、図 14 に示すように径厚比と材軸 方向の長さを一定にして周方向の幅をパラメータにして行う。計算 结界および座屈固有モードの例を表 3 、図 15 に示す。ただし、図 中の小メッシュは要素内の变形を表すために要踏領域を細分割した むのである。解析結果は、比較的粗いメッシュであっても良好な解 が得られている。

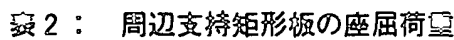
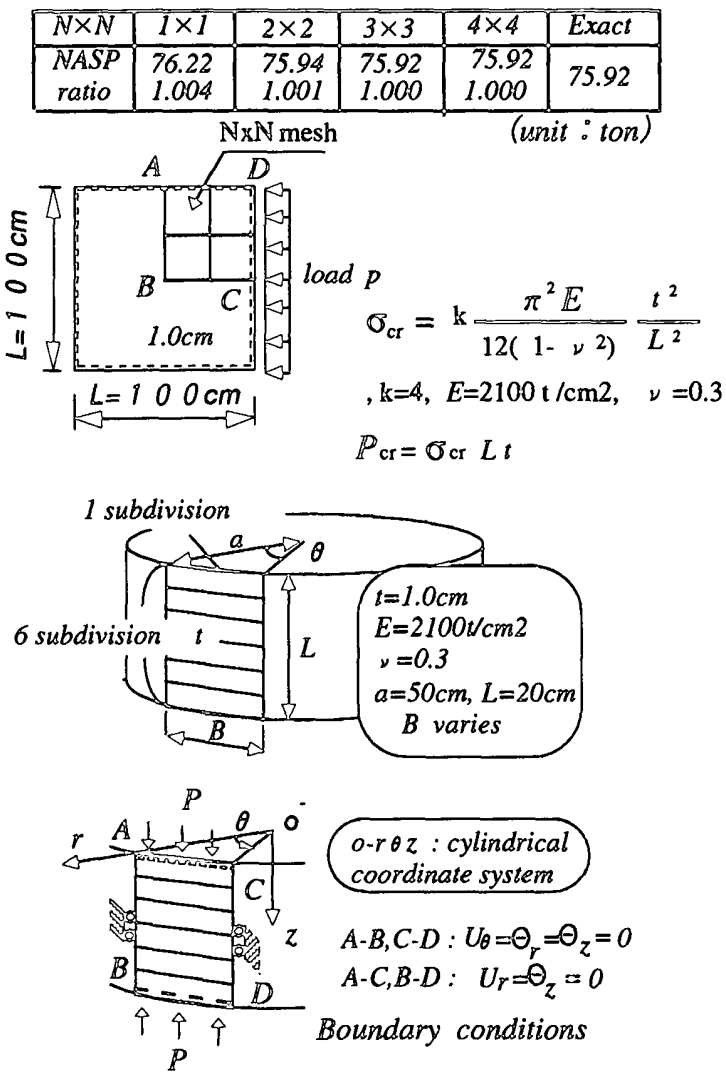

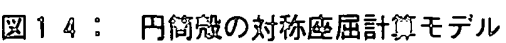

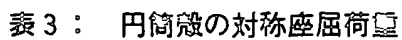

\begin{tabular}{|c|c|c|c|c|c|}
\hline $8 / 360$ & $1 / 8$ & $1 / 16$ & $1 / 32$ & $1 / 64$ & Exact \\
\hline Pcr & 8907 & 8693 & 8658 & 8649 & 8637 \\
ratio & 1.03 & 1.006 & 1.002 & 1.001 & $(\mathrm{~m}=2)$ \\
\hline
\end{tabular}

(unit: ton)

note) Exact value to be obtained by the following formula.

$$
\begin{aligned}
& \sigma=D\left(\frac{m^{2} \pi^{2}}{t L^{2}}+\frac{E}{a^{2} D} \cdot \frac{L^{2}}{m^{2} \pi^{2}}\right) D=\frac{E t^{3}}{12\left(1-\nu^{2}\right)} \\
& P_{\mathrm{cr}}=2 \pi a t \sigma_{c r}
\end{aligned}
$$

$m$ : number of waves for buckling modes

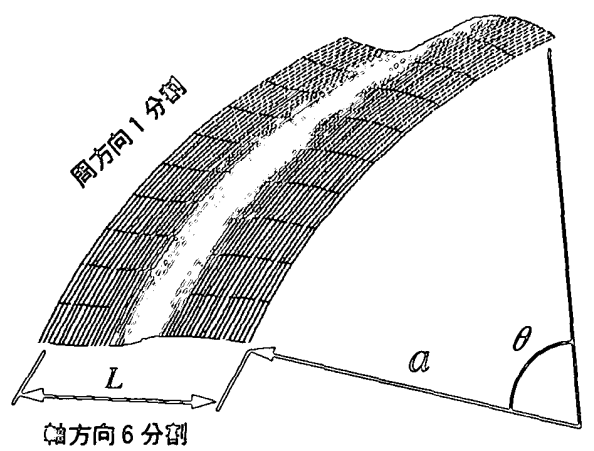

圆 1 5： 㳔称医屈モードの例

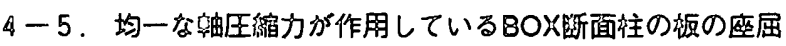

32 要素からなる1/2 対称モデルと計算条件を図 16 に整理してい る。座屈荷重は、荷重增分解析によって得られた軸力〜材軸変位曲 線に吩いて接腺勾配がほとんど露になるときの荷重であると仮定す 
る。座屈後の変形モードの例と座屈荷重を図 17 に示す。柱の座屈 荷重は、BOX断面の一辺の長さをもつ周辺支持矩形板の座屈応力の 式（表 2 参照）から計算した柱の座屈荷重の厳密解にほとんど一致 している。

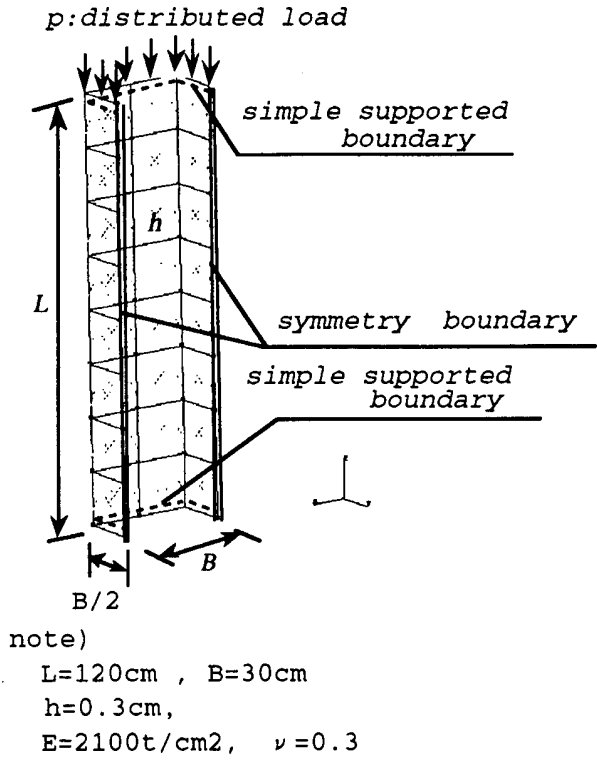

図16：平面シェル要素で搆成されるBOX断面柱

（３２要秦分割）

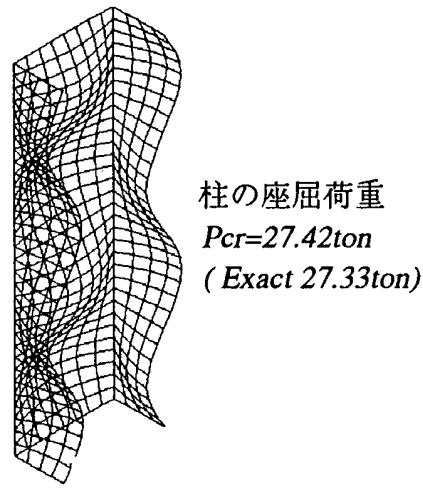

図 $17 ：$ 座屈後の変形モードの例

\section{5. 結論}

本論文で以下の成果を得た。

1. 薄肉構造物を解析するための完全適合型長方形高次平面シェル 要素を提案した。

2.この高次平面シェル要素の要素境界に要素境界接線べクトルを 導入して、それらの回転角成分を節点変位成分に取り入れた。こ のことによって、要素間境界における過不足ない完全な適合条件 が実現された。

3．この要素の要素境界線上における变位場は、面内変位に関して C 0 連続、曲げ変位に関してC 1 連続を満足することを示した。

4.今回提案した要素の曲げおよび面内変形の性能は、従来の高性 能な要素と比較しても同等か、もしくはそれ以上の精度を持つこ とを実証した。

5．この要素を使用する解析では、板の曲げ座屈に関する幾何学的 非線形効果はVon Karman の大娔み板理論に基づく晩み勾配の 2 次
の非線形項で表わされる。この方法の有効性は、基本的な座屈解析 の例題にて十分良好な精度の解を得ることによって実証された。

注 1）シェル構造を対象にした解析のなかで、有限帯板法を用いる 方が効果的である場合がある。有限帯板法は、2 次元の板問題に おいて、一方向の变位分布を少数の既知の連続関数（三角関数の 使用が多い) で近似し、他の方向の要素間の適合条件のみを考え て離散化して自由度を大幅に低減する方法である ${ }^{9)}$ 。しかし、 一方向の変位分布を固定しているので凩用性がなく、有限帯板法 を適用できる対象は限られる。

注 2) 連続な曲面を表わすための円筒シェルや扁平シェル要素におい ても、要素間境界での適合条件を過不足なく満足するものはな w。

注 3）大暁み問題や移動座標系を用いた場合には、これらの係数は 変数である。

\section{参考文献}

1) Mervyn D.OLSON and Terrence W.BEARDEN:A simple flat element revisited, Inter. Journal for Numerical Method in Eng., Vol.14, pp51-68, 1979

2) Sergio IDELSOHN : On the use of deep,shallow or flat shell finite elements for the analysis of thin shell structures, Comput. Meths. Appl. Mech. Engrg. 26, pp. 321330,1981

3) Nicholas CARPENTER, Henryk STOLARSKI and Ted BELYTSCHKO:A flat triangular shell element with improved membrane interpolation, Comuni. in Appl. Numeri.Methods, Vol.1, pp.161-168, 1985

4) J.L.MEEK and H.S.TAN:Instability analysis of thin plates and arbitrary shells using a faceted shell element with loof nodes, Comput. Meths. Appl. Mech. Engrg. 57, pp. $147-170,1986$

5) Kuo-Mo HSIAO :Nonlinear analysis of general shell structures by flat triangular shell element, Computers \& Structures, Vol.25 No.5, pp.665-675, 1987

6) A.F. SALEEB, T.Y.CHANG and W.GRAF:A quadrilateral shell element using a mixed formulation, Computers \& Structures, Vol.26 No.5, pp.787-803, 1987

7) Sung C.LEE and Chan H.YOO : A novel shell element including in-plane torque effect, Computers \& Structures, Vol.28 No.4, pp.505-522, 1988

8) Adnan IBRAHIMBEGOVIC and Edward L. WILSON:A unified formulation for triangular and quadrilateral flat shell elements with six nodal degrees of freedom, Communi. in Appl. Numerical Method,Vol.7,pp.1-9,1991

9）䂣津久一郎, 宫本 博, 山田嘉明, 山本善之: 有限要素法ハンドブック（基 礎編），培風館, pp.406-410, 1981

10) O.C.ツィエンキージイッツ著,吉識雅夫.山田嘉明 監訳: マトリックス 有限要素法三訂版, 培風館, pp253-256, 1985

11) F.K.Bogner, R.L.Fox, and L.A.Schmit :The generation of interelement compatible stiffness and mass matrices by the use of interpolation formulae, Proc. Conf. Matrix Methods in Struct. Mech., AirForce Inst. of Tech., Wright Patterson A.F.Base, Ohio, 1965(October)

12）西村 督, 森迫清貴, 石田修三,上谷宏二 : 増分提動法による立体骨組の大 隐み解析, 構造工学論文集 Vol.39B, pp.73-86, 1993.3

13）石田修三，森迫清貴 : 增分摄動法を導入した一次元複合非線形有限解析法. 日本建築学会構造系論文報告集第397号,pp.73-81, 1989.3

14) Shmuel L.WEISSMAN and Robert L.TAYLOR: Resultant fields for mixed plate bending elements , Comput. Meths.Appl. Mech. Engrg. 79 , pp. 321-355,1990

15) A.F. SALEEB and T.Y.CHANG : An efficient quadrilateral element for plate bending analysis, Intern. Journal for Numerical Method in Eng., Vol.24, pp.11231155,1987

16) M.ORTIZ and G.R.MORRIS :C0 finite element discretization of Kirchhoff s equations of thin plate bending , Intern. Journal for Numerical Methods in Eng., Vol.26, pp.1551-1566, 1988

17) ティモシェンコ,グーディア著,金多潔監訳: 弾性論, コロナ社, pp.41-65, 1977.5

（1997年 1 月 6 日原稿受理，1997年 6 月 24 日採用決定） 